\title{
Restorative Justice in the Basque Peace Process: Some Experiments and Their Lessons
}

\author{
Margarita Zernova
}

\section{Introduction}

In recent decades the focus and scope of the restorative justice movement has expanded. Originally it was confined to changing the way in which contemporary societies react to individual instances of criminal behaviour. Now it includes transforming responses to collective problems, such as political violence, large scale conflicts, gross violations of human rights and historical injustice (Aertsen, 2012; Johnstone, 2011, chapter 9; Staiger, 2010; Walker, 2006a). While the most familiar image of restorative justice continues to involve individual encounters between victims and offenders dealing with an aftermath of 'their' offence, that conceptual model presents a very narrow vision of restorative justice. Today an increasing number of its advocates embrace a transformative conception of restorative justice which goes beyond 'private' dimensions of crime and seeks to apply restorative ideas to the societal level so as to correct social conditions and situations that have caused suffering and injustices (Llewellyn and Philpott, 2014; Sullivan and Tifft, 2006, section V).

One strand in this growing body of literature describes and analyses application of restorative justice in the context of transitional societies, or societies moving either from mass violence to peace or from repressive regimes to democracy. Examples of restorative justice initiatives in transitional contexts range from the South African Truth and Reconciliation Commission (Boraine, 2000; du Toit, 2000; Llewellyn, 2007; Tutu, 1999; Villa-Vicencio, 1998) to gacaca courts in Rwanda (Clark, 2010; Drumbl, 2000) to community-based restorative justice programmes in Northern Ireland (Ellison \& Shirlow, 2008; Eriksson, 2008; McEvoy \& Eriksson, 2006; McEvoy \& Mika, 2001, 2002; Mika \& McEvoy, 2001; Shirlow \& McEvoy, 2008) to a variety of reparative and truth-seeking measures that have been used around the globe in the aftermath of mass atrocities (Aertsen, Arsovska, Rohne, Valiñas \& Vanspauwen, 2012; Govier, 2006; Hayner 2011; Minow, 1998; Quinn, 2009). Proponents observe a conceptual overlap between restorative justice and transitional justice (that is, the conception of justice intervening in periods of political change and aspiring to provide some kinds of justice or repair, or both, in the aftermath of widespread violence and large-scale past abuses (BuckleyZistel, Beck, Brown \& Mieth, 2015; Roht-Arriaza \& Mariezcurrena, 2006; Teitel, 2000, 2015)). It is argued that restorative justice may offer a promising framework for thinking about justice in transitional societies (Doak \& O'Mahony, 2011; Walker, 2006b, chapter 6; Weitekamp, Parmentier, Vanspauwen, Valiñas \& Gerits, 2006). Values underpinning restorative justice may facilitate projects of political reconciliation by calling upon wrongdoers to acknowledge pain and injustice they have caused, offering recognition of victim suffering, providing opportunities for democratic participation, truth-finding, norm-clarification and starting the process of building bridges between deeply divided sectors of society.

At the same time, a number of commentators have cautioned against making ambitious claims about what restorative justice can achieve in transitional settings. Restorative justice was originally designed to respond to 'ordinary' crime in peaceful societies, and it is neither appropriate nor sufficient for dealing with dilemmas faced in transitional contexts (Clamp, 2014; Clamp \& Doak, 2012; Rohne, Arsovska and Aertsen, 2012, pp.19-20; Uprimny and Saffon, 2006; Woolford, 2009, p.119). In such settings, the scale and seriousness of violations stretch conventional restorative practices beyond their limits and present restorative justice theory with numerous conceptual challenges. Atrocities to which restorative justice may seek answers may not have been considered deviant at the time they were committed (Drumbl, 2000, pp.289-90). 
They may have involved large numbers of perpetrators and significant degrees of public participation and complicity (Drumbl, 2000, p.295). The simplistic dichotomy 'victim'/ 'offender' may not account for the complexity of the situation, and individuals may drift between the 'victim' and 'offender' roles over the course of the conflict (Clamp, 2015, pp.2124; Clamp \& Doak, 2012, p.346-7). There may be multiple layers of victimisation and competing narratives of what has happened (Andrieu, 2010; Christodoulidis, 2000, p.195). The state itself may be an aggressor responsible for human rights abuses and oppression of groups of people in its war against certain sectors of society (McEvoy and Eriksson, 2006, p.322). Given such complications, in should not be expected that restorative justice will be able to follow easily its conventional scripts (Woolford, 2009, p.119).

This paper aims to contribute to this critique by examining recent attempts to employ restorative justice in the Basque peace process following ETA's ceasefire. Using the Basque experience, it analyses some of the hidden dangers and tensions which arise when attempts are made to utilize 'traditional' restorative justice approaches and assumptions underlying them in transitional settings. This analysis will be informed by ideas of some critics of restorative justice introduced in the next subsection. Then the historical context of the Basque conflict will be outlined. Next, the paper will proceed to analyse some of the initiatives aiming at promoting social co-existence that have emerged in the wake of ETA's ceasefire. One of these initiatives used a well-established restorative justice method of mediation between individual victims and offenders and attempted to transplant it without alteration from the context of 'ordinary' crime to the context of 'political' crime. It will be argued that the scale and complexity of the conflict that looms behind individual offences in question renders certain assumptions and practices of 'traditional' restorative justice questionable both ethically and politically. Several other initiatives that have emerged recently in the Basque peace process will be discussed, which might suggest a more promising direction for the development of restorative justice in the aftermath of mass violence. They do not fall neatly into the existing models, but they may be allocated a place under the restorative justice 'tent' (Sharpe, 2004). While they have evolved in a very specific context of the Basque country, some of their lessons may have a more general application.

\section{Some concerns of restorative justice critics}

A number of restorative justice critics and advocates belonging to a more radical strand of thinking within the movement have argued that many instances of criminal behaviour stem from much deeper and wider social problems and conflicts. Yet contemporary restorative justice practices often isolate micro-level incidents from their wider terrain and fail to attend to social-structural sources of crime (Dyck, 2000; Mika, 1992; Pavlich, 1996, 2005; Sullivan \& Tifft, 2001; Zernova, 2007). By focusing too much on interpersonal dimensions of crime and refusing to think more 'globally', restorative justice practices may help 'to cover up deeplyrooted divisions in favour of an "ideology of harmony" ' (Dyck, 2000, p.240). This problem is intensified in transitional settings where individual incidents to which restorative justice seeks responses are deeply embedded in macro-level conflicts. So, resolution of individual cases cannot be isolated from their wider political terrain (Clamp, 2014, pp.18-21; Rohne, Arsowska \& Aertsen, 2012, p.19). Restorative practices which centre on interpersonal accommodations between victims and offenders and fail address roots of deeper social conflicts have been described as 'astructurally biased' (Mika, 1992, pp.559-60).

Far from providing forums where wider problems inherent in particular social formations could be uncovered and a 'political debate' (Christie, 1977, p.8) leading to social changes could unfold, 'astructurally biased' restorative practices silence thorny moral, social and political dilemmas. This is part and parcel of what George Pavlich (2005) calls the 'imitor 
paradox': on the one hand, contemporary restorative justice is presented as ethically and practically distinct from the criminal justice system, while, on the other hand, it imitates the criminal justice system's ideological framework. Although restorative justice claims to transcend the moral compass of criminal law, legally defined crimes remain in the background of most contemporary restorative practices as the primary events which have disrupted healthy social conditions. Restorative justice proceeds on the assumption that identities of both victims and offenders are created by legally defined crimes and constitute a starting point in search for justice. Justice is conceptualised as reparation of harm and restoration of the pre-existing social order. The underlying assumption is that the pre-existing order disrupted by crime was healthy, harmonious and just.

When criminal law defines what constitutes harm, 'there is no need to engage the ethical question of whether harm may exist outside of 'crime', or perhaps even whether certain definitions of crime are themselves harmful' (Pavlich, 2005, p.35). When justice is equated to restoration of the pre-existing order, the possibility that breaches of that order may be a legitimate response to an unjust situation is ignored (Woolford, 2009, p.31). The potential for exposing difficult moral, social and political questions to normative debates is frustrated. Restorative practices clinging to formal definitions of crime and seeking to restore the takenfor-granted order operate to reproduce and stabilise, rather than disrupt, the existing legal and political systems (Woolford and Ratner, 2008, p.110).

In transitional contexts, where societies seek to transform themselves, such practices seem ill-suited. In such contexts, normative and political issues are likely to be contested and starkly oppositional interpretations of what happened and why tend to compete with each other. Therefore, disabling deliberative discussions of contentious issues points in the direction of forging a single version of the events. Restorative justice adopting without questioning the framework of criminal law presents a danger of imposing a single 'truth' that conceals more than it reveals, for example, by designating some participants as 'victims' and others as 'perpetrators' when in contexts of mass violence those identities may be muddled. Designations of this kind mask the plurality of individual experiences and may provoke a backlash of rival narratives, frustrating the project of political reconciliation (Andrieu, 2010; Christodoulidis, 2000).

This critique will be returned to later in the paper and applied to a concrete initiative that attempted to use restorative justice in response to ETA terrorism in the Basque country. It will be argued that 'astructurally biased' restorative practices framed by criminal law are deeply problematic. When applied to crime committed with political motivation in the shadow of an unsettled political conflict they deflect attention away from unresolved political issues towards interpersonal resolutions. They hide the complexity and plurality of wrongs involved in the context of a violent political conflict, holding to account only certain wrongdoers and recognising suffering only of certain victims. They help to reinforce a particular 'truth' about the past, which is unlikely to provide the moral common ground necessary for the project of political reconciliation. Such practices thwart the possibility for opening up new justice possibilities beyond the ethical confines of criminal law and serve to protect the existing political system through their prior fundamental attachment to the ideological framework of the criminal justice system. The critique outlined above will be employed to inform the search for more promising directions in which restorative justice could develop in societies seeking political reconciliation. 


\section{The Basque conflict and ETA}

\section{Historical context}

The land of Basques is a triangular area straddling the northwest end of the Pyrenees. It comprises four Spanish provinces and three French territories. Euskera, the Basque language, is believed to pre-date Indo-European languages, and scholars believe that Basques are the 'oldest race' in Europe (Douglass \& Zulaika, 2007, p.27). In the nineteenth century, following a military defeat in the wars which Basques fought against centralizing Spanish governments and a rapid industrialization, which triggered a mass immigration from other parts of Spain, a perception emerged that the Basque culture and language were in danger of extinction (Heiberg, 1989, chapter 3; Muro, 2008, chapter 2). In that climate, modern Basque nationalism was born. For Basque nationalists the only way of preserving the purity of Basque identity was separation of Basque territories from Spain and France and unification of the Basque homeland. Today approximately one in three Basques still subscribe to the goal of Basque independence (Whitfield, 2014, p.27).

When General Francisco Franco came to power in 1939, the dictatorship that was established prized the unity of the Spanish state. Franco's regime did not tolerate manifestations of cultural and linguistic differences and repressed harshly Basque culture, language and identity (Bieter, 2013; Whitfield, 2014, p.40). As a response to what was perceived as an occupation and a cultural genocide by the Spanish state, ETA or Euskadi Ta Askatasuna ('Basque Homeland and Freedom'), an armed separatist organization, was created. Formally founded in 1959 as a student resistance movement, ETA defined itself as a socialist revolutionary organization whose ideology combined Marxism and Basque nationalism. ETA sought national liberation of Basques and a creation of an independent socialist state and saw itself as the vanguard of a stateless nation (Muro, 2008, p.8).

Convinced that the state will never grant independence to Basques without a fight and inspired by revolutionary nationalist movements of the Third World, ETA embarked on a 'revolutionary war'. Deriving legitimacy from Franco's repression, ETA targeted objects perceived as symbols of the Franco regime and Spanish police and military - the 'occupying forces'. ETA's activities were met with arrests, residential searches, police beatings and widespread use of torture of arrestees, and severe punishments. At the time ETA received a considerable degree of popular support (Muro, 2008, pp.108-112). It had the status of a symbol of resistance to Franco's repression (Heiberg, 2007, p.26).

Upon Franco's death in 1975, ETA and its supporters hoped for Basque selfdetermination and a complete break with the past. However, many Franco officials, including the military, secret services, judiciary and the police, retained their positions and thus remained in power. Those guilty of gross violations of human rights were not held accountable and there was no pursuit of 'truth' and 'reconciliation' or other attempts to redress the legacies of the atrocities perpetrated under the dictatorship. This resulted in a multitude of long-term unresolved grievances which are particularly strong in the Basque country where Francoist repression was more severe than in the rest of Spain.

In 1978 Spain acquired a new democratic constitution. While providing for the indissoluble unity of Spain, the constitution gave the Basque country the highest degree of self-rule, compared with other Spanish regions. When the new constitution was voted on in a referendum, only a minority of Basques endorsed it and the majority abstained from voting. For Basque radical nationalists the autonomy granted to the Basque country was not enough. They opposed Spain itself which was viewed as an occupying state (Woodworth, 2001, p.4). This is an Accepted Manuscript of an article published by Taylor \& Francis in Contemporary justice review on 12th July 2017, available online: http://wwww.tandfonline.com/10.1080/10282580.2017.1348899 
They regarded the Spanish constitution illegitimate and Spanish transition to democracy false (Muro, 2008, pp.124-5). On this view, until the seven Basque provinces are united and the Basque homeland acquires independence from Spain and France, the Basque nation will remain a colony without historic personality and political rights (Heiberg, 2007, p.30).

Recruitment to ETA continued and violence escalated. In the 1980s ETA started a trend of indiscriminate violence, planting bombs in train stations and resort areas, assassinating those who were considered to be collaborating with the Spanish government, killing not only the intended victims but also passers-by with car bombs, subjecting businesses to extortion ('revolutionary taxation') and kidnapping those who refused to pay. In the 1990s the circle of targets was further widened to include politicians, lawyers, judges, journalists, academics and anybody who was critical of ETA's cause (Heiberg, 2007, p.28). According to the most accurate figures to the date, as part of its violent campaign, ETA caused deaths of 837 victims, wounded between 2,365 and 2,600 people, kidnapped 77 individuals and subjected thousands of businesses to extortion (Carmena, Landa, Múgica \& Uriarte, 2013). On top of that, since the 1990s kale borroka (or 'street struggle') was practised by young ETA supporters as a form of political vandalism which cost many millions of euros in property damage every year.

It is important to note that ETA was not simply an armed organization acting in isolation. It was the backbone of a complex structure of interlinked civil society organisations constituting the nationalist left community (Bullain, 2011). The nationalist left was both a social and political movement which provided an infrastructure for radical nationalism and included, apart from ETA, an anti-systemic network of labour organizations, youth groups, cultural societies, prisoner support organizations and its own bars. The nationalist left presented a micro-society with its own symbols, narratives and discourses and provided a space for socialization and reproduction of their radical ideas (Muro, 2008, chapter 5). It had its own electoral coalition Herri Batasuna ('The People United') which shared ETA's political goals and never condemned its acts of violence.

\section{State repression of the nationalist left}

As mentioned above, during the Franco regime ETA's actions were responded to with brutal repression. Thousands of Basques were detained, held incommunicado, denied legal representation, interrogated with the use of torture and, if brought before courts, tried in military tribunals. Since the early 1970s, checkpoints, residential searches and states of emergency imposed in response to ETA violence were a regular occurrence. The situation did not change radically upon transition to democracy (Heiberg, 2007, p.41). Accused ETA militants continued to be held incommunicado, without access to family or a lawyer, denied legal rights, subjected to torture and tried before the Audiencia Nacional - a special court designed to try terrorism-related offences. Yet worse was to come.

The government started to hire and fund paramilitaries to target ETA. One wellknown group was the death squad Batallón Vasco Español operating in the late 1970s (Woodworth, 2001, chapter 3). In the 1980s the socialist government of González engaged in what became known as the 'dirty war' (Woodworth, 2001, Part II). The Grupos Antiterroristas de Liberación ('Anti-Terrorist Liberation Groups' or GAL) were formed secretly by the Spanish interior ministry and consisted of French and Portuguese mercenary assassins. Eventually GAL activities and the role of governmental officials behind them were revealed. The guilty were prosecuted and convicted, but they were promptly released from prison (Cuadra, 2009). The 'dirty war' by the Spanish government proved counterproductive, contributing to the acute sense of injustice on the part of the nationalist left and promoting the image of the state as engaging in criminal activities with impunity. It 
undermined the legitimacy of Spain's democracy, created new ETA martyrs, recruits and sympathisers (Bieter, 2013; Whitfield, 2014, p.60; Woodworth, 2001, chapter 25).

The socialist government of González also instituted a new penal policy that involved dispersal of ETA prisoners in an attempt to rupture their internal cohesion. Until then they had been concentrated in Basque prisons. Since 1988, they have been dispersed throughout Spain and subjected to new harsh regimes. Prisoner dispersal has no basis in Spanish penal law and has been described as illegal and unconstitutional (Elbal, 2014). The measure punishes severely not only inmates but also their families who have to travel hundreds, and in some cases more than a thousand, of kilometres for visits. This compounds the militant Basques' sense of victimization.

In the wake of the 9/11 attacks additional changes to criminal law and criminal procedure were introduced. The period for incommunicado detentions was extended, privileges of prisoners serving sentences for terrorism-related offences were reduced and the requirement that such prisoners serve the full term of their sentence was introduced.

Definitions of terrorism were broadened so as to include kale borroka (political vandalism), as well as crimes of 'collaborating' with terrorist groups and 'glorification' of terrorism (so that praising or publicly justifying terrorism became a terrorist offence). Such legal changes enabled prosecutions of a large number of individuals and organisations, ranging from youth involved in kale borroka to prisoner support organizations to bars accused of fund-raising for ETA to journalists and editors of a Basque language newspaper (Whitfield, 2014, chapter 3). The culmination of the state repression carried out as part of counter-terrorist policies was the illegalization in 2003 of ETA's political wing Herri Batasuna mentioned above. This measure disenfranchised the Basques who consistently voted Batasuna, in addition to violating freedoms of association, assembly and expression.

There were numerous reports of international bodies, such as Human Rights Watch, Amnesty International, European Committee for the Prevention of Torture and the UN special rapporteurs documenting police torture and mistreatment of arrestees suspected of terrorism-related offences in the Basque country (Amnesty International, 2007, 2009a, 2009b; Carmena, Landa, Múgica \& Uriarte, 2013; Whitfield, 2014, pp.125-8). On a number of occasions the European Court of Human Rights has condemned Spain for failing to carry out effective investigations of allegations of torture of suspects detained in relation to ETA terrorism. When police officials were investigated for allegations of torture and maltreatment, they were found not guilty, or, even if found guilty, later released promptly, which resulted in effective impunity (Amnesty International, 2007, 2009a). Additionally, in 2012 the European Court of Human Rights has found Spain guilty of violating the European Convention on Human Rights through the application of the so called 'Parot doctrine', a judgement which forced Spain to release sixty-three ETA prisoners.

Basque radical nationalists believe that Spain is not a democratic state and that the Basque homeland is occupied and oppressed by Spain. Police torture and human rights abuses, state-sponsored terrorism and repressive anti-terrorist penitentiary policies have deepened the sense of enduring injustice felt by the nationalist left and helped to justify the use of violence as a reaction to decades - or even centuries - of Spanish aggression (Muro, 2017).

\section{Ceasefire and peace process}

On the $20^{\text {th }}$ of October 2011 ETA announced a 'definitive end of its armed activity'. There were numerous factors that have contributed to that long awaited announcement: successful police action by both Spain and France that virtually destroyed ETA, the revolt of Basque 
society against ETA's violence (including even those who supported ETA's goals) and the realization by the nationalist left that the continuation of violence was counterproductive and that the goal of Basque independence could be pursued more effectively by peaceful means. No formal negotiations took place between ETA and the Spanish government and no peace agreement was reached, as the Spanish government refused to engage in direct negotiations with ETA on the grounds that talking to terrorists would confer legitimacy upon their cause. Rather, with the assistance of international facilitators, ETA took unilateral steps resulting in the renunciation of violence.

Two months later the conservative party Partido Popular, led by Mariano Rajoy, came to power. Rajoy's government ignored ETA's call to enter into a dialogue to address the consequences of the conflict and refused to move ETA prisoners to the Basque country and release seriously ill prisoners. It continued to pursue and repress what was left of ETA with police and legal means, while demanding ETA's unconditional dissolution. ETA made a further unilateral step announcing decommissioning of its weapons. Rajoy's government offered no assistance in the process of disarmament, indeed, it opposed the process by criminalising international actors who attempted to assist ETA in it (eitb.eus, 2014; Elejabarrieta, 2015, p.160). Repressive anti-terrorist penitentiary policies continue (such as dispersal of ETA prisoners, lengthy incommunicado detentions, systematic refusal of exit permits, automatic classification of ETA prisoners into first grade and imposing exceptionally stringent conditions for progressing into third grade), in addition to criminalising the whole range of left wing Basque nationalists sympathising with ETA (Landa, Echano, Etxebarria \& Garro, 2014). The unwillingness of the Spanish government in assisting ETA to disarm and bring it to an orderly end, combined with its exceptional anti-terrorist penitentiary policy which lost its justification following ETA's permanent ceasefire (Landa, 2012), has lead to accusations that ETA's end is not beneficial for the Spanish government. Terrorism shifts focus away from the Basque nationalist demands and therefore is preferable to a peaceful campaign for Basque independence (Whitfield, 2014, pp.301-2, 2015; Woodworth, 2014). It is argued that the Spanish government is sabotaging the Basque peace process because a pursuit of Basque independence by peaceful democratic means could open a second front of separatism in Spain (alongside Catalonia), threatening the unity of Spain and triggering a fullblown territorial crisis (Elejabarrieta, 2015; La Vangaurdia, 2015; Ormazabal, 2016).

Today the Basque society remains deeply polarized between non-nationalists who wish to remain firmly integrated in Spain and nationalists who demand independence or at least the right to decide what the relationship of the Basque country to Spain should be. Yet, despite the sharp divisions, with the end of ETA's violence, a slow process of healing wounds caused over decades of violence in the Basque country began. The nationalist left has made attempts at apology to victims of ETA (Munarriz, 2012, pp. 200-1) and expressed 'deep regret' for pain and suffering caused by ETA's armed actions and for the lack of sensitivity towards ETA's victims (Izquierda Abertzale, 2012). ETA prisoners issued a statement in which they rejected violence and recognized the suffering and multilateral harm that has been inflicted (Aizpeolea, 2013), and a group of former ETA prisoners joined them in expressing a full commitment to the pursuit of their goals by democratic means, as well as accepting responsibility for all consequences of the conflict (BBC, 2014). Yet, for many Basques and almost all Spaniards this is insufficient. They call for ETA's disarmament and dissolution. Victims of ETA, as represented by victims of terrorism associations, demand that ETA condemns its entire history (Reunión de Asociaciones y Fundaciones de Victimas del Terrorismo, 2010). For ETA, however, such condemnation is unthinkable because the organization retains a firm dedication to its goals and a strong sense of political achievement of its struggle in the survival of its goals (Whitfield 2014, pp. 234, 282). Following the ceasefire, the political demands of the 
nationalist left are pursued by the pro-independence coalition Euskal Herria Bildu ('Basque Country Unite') - the second political force in the Basque country.

Social reconciliation remains a distant ideal in the Basque country. One important obstacle is presented by an acute sense of victimization felt by the nationalist left. It stems from the fact that there was no full acknowledgment of the crimes committed against them under Franco's regime, and upon the transition to democracy the nationalist left suffered a multitude of violations of human rights and violent crimes committed against them by the State and paramilitaries (as has been explained above). The nationalist left puts forward a list of victims of the state repression: since 1960, 10,000 were tortured, 7,000 imprisoned, 50,000 detained and 474 killed (Agirre, 2012). There is a perception on the part of radical Basque nationalists that while the criminal justice system pursued with full force and punished severely crimes of the nationalist left, crimes committed against them resulted in 'an impunity of incredible proportions' (Naiz, 2016). It is argued that, while ETA ended its armed activity, all violence has not ended, because inhumane prison policy and state repression of the nationalist left continue (El País, 2015; Izquierda Abertzale, 2012). The nationalist left has called for the ending of the state violence, measures of transitional justice and the creation of an international and independent truth commission (Goirizelaia, 2012; Izquierda Abertzale, 2012). However, establishing a truth commission at the instigation of the nationalist left would have legitimized ETA's struggle (Whitfield, 2014, p.184), which is unacceptable for the Spanish government. The Spanish government has rejected the relevance of transitional justice in Basque country denying the existence of the armed conflict between ETA and the Spanish state and framing the problem as ETA terrorism (Naiz, 2015). The recognition of the existence of a military conflict would have triggered the application of international humanitarian law, as well as undermining the legitimacy of the Spanish state.

Nevertheless, numerous initiatives aiming at truth-seeking, analysis of what happened, addressing suffering of victims and promoting coexistence were launched (Agirre, 2012; Bengoetxea, 2013; Whitfield, 2014, pp.280-2). Some of them may be informative for those with an interest in restorative justice. These initiatives will be discussed in the remaining part of this paper and their lessons will be analysed with reference to ideas of critics of restorative justice outlined earlier.

\section{Restorative initiatives}

\section{Victim-offender mediation programme}

In September 2011, shortly before ETA's declaration of a 'definitive end of its armed activity', media reports revealed the existence of a restorative justice programme in the Basque country that involved encounters between victims of ETA violence and ex-ETA militants serving prison sentences for their terrorist offences (Ceberio, 2011a, 2011b). These offenders belonged to the so-called Nanclares group (or the 'group of prisoners committed to the irreversible peace process', as they called themselves). As noted above, for years subsequent Spanish governments pursued the policy of dispersal of ETA prisoners, so inmates were spread around Spanish prisons. The socialist government of Zapatero allowed the prisoners who broke away from ETA to be transferred to the Basque prison of Nanclares de Oca. These were twenty-and-something prisoners who had distanced themselves from ETA, its 'environment' and goals, renounced the organisation and violence publicly, asked their victims for forgiveness, accepted responsibility to pay them civil compensation, and agreed to collaborate with the criminal justice system. 
In 2010 some of these ex-ETA militants petitioned the Basque government's Directorate for the Attention to Victims of Terrorism, requesting an opportunity to meet their victims and ask for forgiveness (Olalde, 2013, p.35). The Basque and the Central governments (both of which were controlled by the socialist party) supported and promoted the mediation programme that was established as a result of that request. A group of professional mediators was employed to facilitate encounters between victims (who were survivors of terrorist attacks or their relatives) and these offenders. The offenders in question were serving prison sentences for assassinations, attempted assassinations and kidnaps (Ríos, 2013). All of them had been imprisoned at least for thirty years and had already spent at least fifteen years in prison.

In total, fourteen restorative meetings took place. They took form of victim-offender mediation (Umbreit, Coates \& Vos, 2006; Wright, 1996; Zehr, 1990). Some of these encounters brought together victims and offenders from the same terrorist act, while others involved meetings between victims and offenders from different attacks. The aim of the programme was to promote a restorative dialogue and facilitate individual healing and closure (Pascual, 2013). The encounters between victims and offenders were voluntary. As noted above, offenders themselves initiated the meetings. Importantly, they received absolutely no penitentiary benefits as a result of their participation (Ríos, 2013). Their reasons for taking part in restorative encounters were largely altruistic and included helping victims, asking for forgiveness, serving as an example for others and contributing towards the construction of peace in the Basque country (Pascual, 2013, p.123). Victims participated for a variety of personal reasons (for example, some thought that their assassinated relative would have liked them to participate, others were motivated by religious faith, yet others could not articulate exact reasons but knew that they 'always wanted to do it'). Many victims took part in the programme because they wanted to act as an example for their children and grandchildren and help to build the Basque country free of hatred, where one day children of terrorists could coexist with children of victims of terrorist attacks without fear and animosity (Lozano, 2013, p.83, 91; Pascual, 2013, pp.119-20, 124; Ceberio, 2011d).

The team of professional mediators carefully assessed attitudes of offenders in preliminary meetings so as to evaluate their suitability for restorative encounters. This was necessary to prevent a possibility of re-victimising victims. So, only offenders who had distanced themselves from ETA and rejected its ideology were allowed to take part. Those who still justified their crimes were precluded from participation (Pascual, 2013, p.128). The mediators were neutral and did not belong to any political party or other organisation that could compromise their neutrality. While they were perfectly aware of the political nature of crimes carried out by the offenders they worked with, a conscious effort was made to de-politicise these crimes. Terrorist offences were treated no differently than any other serious crimes committed without political motives. It was believed that such depoliticisation made it possible to see clearly the essence of what had happened: concrete acts of violence carried out by offenders against their victims. Such an approach, it was argued, offered an opportunity to help individual victims and to contribute to pacification of the Basque country (Segovia, J. L., 2013, p.173).

The mediators acknowledged that very often the offenders taking part in restorative encounters were victims themselves: the majority of them had been subjected to maltreatment and torture by the police and in some cases they were also victims of terrorist attacks (Pascual, 2013, p.127). Yet, this victimization was not seen as relevant to restorative encounters carried out as part of the programme (Segovia, J.L., 2013, p.173).

When the two parties met, victims sought answers to questions which only the offenders could answer. They wanted to know why their loved ones had been assassinated 
(Ríos, 2013, pp.199-200). They also wanted to know details of the assassinations which nobody apart from the offenders could provide (Ríos, 2013, pp.200-202). Victims described to offenders the immense pain they had suffered when they had lost their loved ones and the dramatic changes in their lives which that loss had caused (Ceberio, 2012c; Ríos, 2013).

What often aggravated their pain, victims explained, was the social isolation and cruel ostracism which many experienced following the terrorist attacks (Lozano, 2013, p.104; Segovia, 2013, p.158). Often people in their proximity assumed that the assassinated relative was not innocent: they 'must have done something' to provoke a terrorist attack upon themselves. Victims described how, following assassinations, neighbours stopped talking to them. Insults were written on doors of their houses. Demonstrations in support of ETA that were passing by stopped under their balconies to shout loudly 'Viva ETA!' (Ríos, 2013, p.197).

In the course of a restorative dialogue, offenders explained reasons for the atrocities they had committed and their context. It transpired that the majority joined ETA in the 1970s, when they were 16 or 17 years old and saw the membership of the organization as an honour and a fulfilment of their dreams. They believed that any means, including violence, were legitimate in the struggle against Franco's dictatorship (Pascual, 2013, p.133). Often they got radicalized and joined ETA following torture or killing of a relative or a friend by the State security forces (Ríos, 2013, p.194). Offenders explained how the armed separatist group to which they belonged imposed upon them a particular worldview, and how the ideology to which the group subscribed justified violence (Ríos, 2013, p.208). They saw their actions as heroic, necessary to save the identity of the Basque people oppressed politically by the Spanish state occupying their land. However, as ETA's strategy changed and killings became more and more indiscriminate, many started questioning the group's actions at first from the strategic point of view and then from the ethical one. Some even felt liberated upon imprisonment because they no longer had to kill (Ríos, 2013, p.194). The offenders also described how, years later, in the solitude of their prison cells, they repented their crimes and took a decision to leave ETA. They admitted that their militancy was a huge mistake that had an explanation but no justification - the mistake that caused immense suffering not only to their victims, but also to their own families and themselves (Ríos, 2013; Segovia, J.L., 2013).

As victims learned more and more about their offenders, their lives before and after ETA militancy and the destructive effect which ETA membership had had on them and their families, the pre-existing image of offenders as 'monsters' gradually melted away in their eyes. Victims began to see their offenders as ordinary human beings who had done terrible things in the past but now acknowledged the harm that they had caused, repented their wrongdoings and assumed moral responsibility for their actions. There were even signs of compassion that some victims felt towards their offenders and expressions of forgiveness. Encounters concluded with handshakes or hugs, and some victims and offenders agreed to stay in touch (Ríos, 2013, p.215-16).

Although there was no official evaluation of the programme, subsequent interviews with victims and offenders that appeared in the media indicate that both parties found the encounters helpful (Ceberio, 2011c, 2012d, 2012e, 2012f, 2013; Gómez 2013). The victims valued the opportunity to ask questions which only the offenders could answer, express their pain looking into eyes of those who had caused it, see repentance of the offenders and hear their apology. Offenders felt that meeting victims and hearing their stories helped them realise the full extent of the suffering they had caused, express contrition, and offered an opportunity for moral transformation and regeneration (Carrasco, 2013). Mediators facilitating the encounters and the promoters of the programme also strongly believed that the 
programme was successful and capable of achieving much more than the traditional criminal justice system could ever achieve (Olalde, 2013, p.67; Urkijo and Gallizo, 2013).

\section{Co-existence workshops}

As has been noted above, recently various initiatives aiming at promotion of peaceful coexistence and social reconciliation have been launched in the Basque country. Some of them will be discussed here. Although they did not take the 'classic' form of restorative justice, values underpinning them fit well with the restorative justice philosophy. One such experiment was conducted in the Nanclares prison in 2011. The programme was entitled 'Workshops of Coexistence' and brought together a dozen ETA prisoners willing to participate in the process of peacebuilding in the Basque country and ETA victims, social activists, academics, politicians and journalists (Bieter, 2013; Ceberio, 2012a, 2012b; Etxebarria, 2013, pp.298-302). The workshops were requested by the prisoners who had assumed responsibility for the suffering they had caused and thought that collective reflections and debates with people from various sectors of the society subscribing to diverse political viewpoints were needed to help overcome some of the obstacles to peaceful coexistence in the aftermath of violence (Ceberio, 2012b). Among issues discussed in the workshops were violence, experiences of victimization, healing personal and social wounds, critical re-assessment of the past, truth and reconciliation, new forms of social coexistence in the aftermath of violence, and contributions which prisoners could make towards it. The programme was supported by both Central government of Zapatero and the Basque government.

In two of these workshops - particularly intense emotionally - three victims of ETA terrorism took part. These victims noted that the ex-ETA militants participating in the workshop were very critical of ETA; not only did they recognize the harm they had caused but also sought to reverse it (Ceberio, 2012a). One of these victims was a well-known journalist and ETA's critic who had survived ETA's attack, but was seriously wounded and became disabled for life. In a subsequent newspaper interview, this victim acknowledged that when he told the offenders participating in the workshop his story, he saw a desire on their part to take responsibility for the pain caused, engage in self-criticism and take that selfcriticism outside of prison walls. At the end of the workshop, two prisoners approached him and apologised for the attack which he had suffered, even though they were not direct perpetrators (Ceberio, 2012a).

Fathers of the other two victims who took part in the workshops had been assassinated by CAA (Comandos Autónomos Anticapitalistas) - a splinter group from ETA. One of the topics discussed was the social atmosphere at the time of assassinations (early 1980s) where offenders were justified and victims blamed. So, the victims had to deal not only with the loss of their fathers, but also the hostile social environment which added to their pain. Such stories made the workshop participants question not only ETA's violence, but also the social context which helped to sustain it (Ceberio, 2012a, 2012b; Etxebarria, 2013, p.301).

Another topic discussed was the existence of multiple forms of violence and multiple victims on different sides of the Basque conflict. That included violence employed by the state in repressing ETA, for example, violence of GAL and state agencies, such as police and security services. ETA prisoners recognized that they belonged to an organization which was one of the parties responsible for suffering of many Basque families. However, they also stressed that suffering of victims of all forms of violence needs to be recognised, so that the 
post-ETA period in the Basque country is constructed on a more accurate narrative (Ceberio, 2012a, 2012b).

Workshop participants discussed contributions which they could make towards social reconciliation and peacebuilding in the aftermath of violence. They talked about practical steps they could take to encourage a critical re-assessment of the past that goes beyond the intra-personal level, for example, by giving interviews, publishing articles and communiques, participating in tributes to victims and various public forums. It was agreed that ETA prisoners should make their stories heard by the world outside, explain to the Basque society how and why they reached the conclusion that violence was not the right path to take and look for a dialogue with victims to help heal their wounds (Ceberio, 2012a; Etxebarria, 2013, p.300).

\section{The Glencree Initiative}

Another initiative that fits well with values of the restorative paradigm started in 2007 and was promoted by the Directorate of the Basque government for the Attention to Victims of Terrorism. It brought together twenty-seven victims of different types of violence (Rivas, 2012). The initiative was named after the Glencree Centre for Peace and Reconciliation in the Irish town of Enniskerry where they met for the first time. Among those who took part were people whose relatives were kidnapped, tortured and assassinated by ETA, GAL or extreme right organisations, as well as direct victims of the police torture and people whose relatives were tortured or killed by the police (Lokarri, 2012).

When these victims first met, the emotional atmosphere was tense and participants in the meetings felt nervous. They were aware that they faced people who held very different political views. However, as the meetings unfolded and individual stories of victimisation and suffering were shared, the importance of the political differences subsided. The realisation grew among the participants that they had a lot in common and were united by the pain and injustice they had experienced (Iniciativa Glencree, 2012; Naiz, 2012).

Participants in the Glencree initiative discussed in their meetings a variety of topics related to experiences of victimization, acknowledgment (or lack of it) of their suffering by the society, reparation, historic memory, peace and co-existence. For five years they congregated discreetly, so as to avoid media and political interference, but in 2012 they issued a declaration stating the message of the group to the public (eitb.eus, 2012a). The group emphasised that they did not want to identify themselves utilising definitions and concepts which are typically used to describe them (such as the concept of 'victims'). Nevertheless, they acknowledged that there was a trait that characterised them all: they had been personally affected by political violence which has caused them long and unfair suffering. They explained that they wanted to use their personal experiences to make a positive contribution, as a group, to peaceful co-existence in the Basque country. Despite their ideological differences, they have broken barriers that separated them and looked beyond stereotypes to start a dialogue and search for a common ground. Finally, they called those responsible for damage caused to accept their responsibilities and the society to make their own self-critical revision of the past through commitment to truth and justice (Iglesias, 2012; Iniciativa Glencree, 2012; Rivas, 2012; Sola, 2012).

The Glencree initiative inspired a subsequent programme that was piloted in 2013 with the support of the Basque government in three Basque municipalities and a university. The idea behind the programme was to create a space where ordinary Basque citizens could This is an Accepted Manuscript of an article published by Taylor \& Francis in Contemporary justice review on 12th July 2017, available online: http://wwww.tandfonline.com/10.1080/10282580.2017.1348899 
engage in a dialogue and collective reflection about politically-motivated violence, its consequences and social co-existence in its aftermath. Eighty-eight citizens took part. They were shown a video about the dialogue among victims of different forms of violence that took place as a part of the Glencree initiative. The video was followed by a group discussion. The aspiration of the project was to present citizens with a pedagogical tool aiming to spark a debate. An independent evaluation of the pilot programme confirmed the need for such debates and its educative value for Basque citizens (Elorza, 2014).

A related initiative was an education programme promoted by the Basque government which involved victims visiting Basque colleges and providing their testimonies to students. Seventeen victims - including victims of ETA, GAL, Batallión Vasco Español and police torture - took part in this programme the aim of which was to de-legitimate terrorism and vindicate peaceful coexistence (Aizpeolea, 2015a; eitb.eus 2013). As one of the victims taking part in the programme explained, they wanted to send a message to young people that while hatred is a natural emotion following the assassination of a loved one, it is necessary to leave that feeling behind. It is possible to transform self-destructive emotions into something positive, in particular, work towards peaceful coexistence in the aftermath of violence (Aizpeolea, 2015b).

\section{Errenteria forums}

In 2013, a series of public forums was held in Errenteria, a town in the Basque nationalist heartland of Gipuzkoa province (Burgueño, 2013; Hedgecoe, 2014). The town was one of the places most affected by separatist violence where over 800 lives were lost. The forums brought together some 300 people from different sides of the Basque conflict: there were relatives of ETA and GAL victims, politicians who had been on ETA's hitlist and former ETA militants, including those who had been tortured by the police. The nationalist mayor promoted the initiative. In his inaugural speech he reached out to both sides of the conflict. Testimonies from both sides were heard, often controversial, but they were listened to with respect. Documentary films and theatrical plays were presented the objective of which was to spark personal and collective reflection about violence, its social consequences, and coexistence in its aftermath.

One of the documentaries that were screened concerned ETA and the Basque society. The screening was followed by a colloquium in which its protagonists, representing different sides in the Basque conflict, took part and answered questions from members of the audience. The victims taking part in the colloquium recognised that there were many victims who manifested a 'thirst for vengeance'. In contrast, they wanted to send a message of reconciliation. In the words of one of them (whose father died as a result of police torture), 'it is necessary to transform pain into activities aimed at the resolution of the conflict' (Eizmendi, 2012). Or, as another victim who had experienced violence from both sides of the conflict (her husband had been subjected to francoist repression and incarceration and then killed by ETA) has suggested, it was necessary to leave hatred behind and work towards rebuilding the country (Eizmendi, 2012).

Other initiatives promoting a dialogue between people from different sides of the conflict followed, with Errenteria converting into a 'small laboratory of co-existence' (Sainz, 2016). One example involved a series of meetings of a group of eighteen local citizens holding opposing political views taking place over three-and-a-half years. In the process, as one of the participants explained, 'we have changed, after questioning what we used to take for granted and listening to understand each other' (eitb.eus, 2016). 


\section{Restorative justice initiatives in the Basque peace process: an assessment}

So far this paper has outlined several initiatives that have emerged as part of the Basque peace process. One of them took a familiar form of victim-offender mediation and others, while they do not fall neatly into the existing categories of restorative practices, mirror restorative justice values (such as the emphasis on dialogue, acknowledgment of victim suffering and past injustices, aspiration to transform past pain into something positive, move towards reconciliation, provide opportunities for norm-clarification and truth-finding). What lessons can be learned from these initiatives? Can 'traditional' restorative justice methods be simply transplanted from the context of 'ordinary' crime to the context of 'political' crime and, if yes, with what consequences? To these questions the discussion will now turn.

\section{VOM}

The victim-offender mediation programme described above was not without its critics. Most ETA prisoners and the nationalist left rejected it in favour of transitional justice measures that would allow for collective amnesties (Goirizelaia, 2012; Sainz, 2012; Varona, 2013, p.221; 2014, pp.326, 237). Certain victims' associations criticized it on the grounds that it presented a 'soft' form of justice coming close to impunity, obviously overlooking the fact that participation in the programme gave offenders no penitentiary benefits (Varona, 2014, p.326). Some victims also questioned the sincerity of offenders' repentance, given that their contrition was not accompanied by collaboration with the criminal justice system. As a consequence, many crimes committed by ETA remain unresolved (Martínez, 2012; Reyero, 2015). Such criticisms by victims' associations - who are a powerful political lobby in Spain - were instrumental in the termination of the programme by the right wing Partido Popular government that came to power in November 2011 (Gastaca, 2013a).

Yet the programme was problematic for different reasons. The offenders taking part in it emphasised that all their violent actions were carried out in the name of ETA (Pascual, 2013, p.115). And, as has been explained in the 'Historical context' subsection above, ETA's ideology combined Marxism and Basque nationalism and its goals involved national liberation of the Basques and a creation of a socialist state. As has been pointed out earlier, programme facilitators stressed that the political level did not interest them (Ríos, 2013, p.181). Having adopted an 'apolitical' stance, the programme, without much questioning, embraced the framework of criminal law. Within that framework, the problem was defined as violent crimes of ETA and a conscious effort was made to de-politicise and de-ideologise them in the belief that the essence of terrorist offences is no different from 'ordinary' crimes and can be reduced to a violation of one person by another (Segovia, J.-L., 2013, p.173). Drawing a veil over ETA's political motivations resulted in a form of 'interpretative denial': 'what happened is not what you think it is, not what it looks like, not what you call it' (Cohen, 2001, p.7). By interpreting events as interpersonal violence devoid of its political context, the VOM programme helped to conceal the fact that ETA's violence, however unacceptable, questioned the existing social and constitutional order. The programme implicitly assumed a moral and political consensus where none existed.

As noted above, mediators facilitating restorative encounters claimed to be neutral since they did not belong to any political party or another organisation that could compromise their neutrality. Yet that claim overlooks the fact that they had positioned restorative justice as contingent on legally defined crime and construed it as a way of dealing with the aftermath of legally defined offences. In doing so, they unintentionally took a particular political stance. To the extent that criminal law is fundamental to maintenance and preservation of the established political order (Quinney, 1970), the programme mediators have subscribed to the 
protection of the existing political system. The political stance adopted by them deflected questions of justice away from discussions of politically controversial issues and disabled possibilities of conceptualizing justice outside of the narrow ethical confines of criminal law.

While mediators facilitating the restorative encounters saw the role of the victims as self-evident, it was acknowledged that in the case of offenders the situation was 'a little bit more controversial' (Pascual, 2013, p.127). This was because often offenders themselves had been victims of police maltreatment and torture before they joined ETA or upon detention. It was even recognized that in some cases police torture constituted a 'legitimizing' factor for entering ETA (Ríos, 2013, p.213). Yet, such complications were treated as immaterial for the purposes of restorative justice, as long as offenders did not attempt to use their experiences of victimization to justify their crimes. The programme embraced definitions of offenders supplied by the criminal justice system and viewed individual offenders as the only generators of harms that required amelioration. Offenders who were considered 'stagnant in their personal evolution' and 'incapable of maintaining the discourse of repentance and apology as long as the State does not at the same time recognize its quota of harm done' (Pascual, 2013, p.134) were excluded from participation in the programme. The objective was to avoid hurting victims (Pascual, 2013, p.128). The unintended consequence was that implicitly the programme supported a particular narrative which defined the problem as senseless violence of ETA and recognized only one type of victims - victims of ETA violence. Yet, there are deep divisions in the Basque society regarding the interpretations of what happened and why, so multiple narratives compete with each other (Ormazabal, S., 2012). Excluding from participation in the programme those who might have challenged the narrative reinforced by the programme inadvertently helped to hide the plurality and complexity of wrongs involved. It served to promote a single 'truth' which over-simplified complicated historical events and, many would argue, distorted them.

The victim-offender mediation model which was adopted presented an approach which is individualized, private and exclusionary in nature (Johnstone, 2011, pp.124, 131; Zehr, 1990, p.256). It precluded a possibility for participation of a wider circle of citizens, resulting in a loss of opportunities for collective deliberations and norm clarifications. While such a loss may be unfortunate in cases of 'ordinary' crime, it is even more so in situations where crime has been committed with a political motivation in the shadow of what a sizable political sector in the Basque country perceives as an unresolved political conflict with deep historical roots. It can be argued that the mediation programme presented a classic example of what critics whose ideas have been outlined at the beginning of this paper call 'astructurally biased' restorative justice which promotes an 'ideology of harmony' and diverts attention away from deeply rooted sources of the conflict and towards interpersonal resolutions (Dyck, 2000; Mika, 1992). Such restorative justice fails to pay due regard to wider power relations which might have provoked the instances of individual violence in the first place and thus helps to reinforce the status quo (Pavlich, 1996, 2005; Woolford and Ratner, 2008).

However, to conclude this is not the same as to deny the usefulness of such encounters in facilitating individual healing and closure. Rather, it is to highlight the hidden dangers of the model of restorative justice adopted within the programme and invite a search for more fruitful ways of employing restorative justice values and approaches in a society transitioning from violence to non-violence, while the political conflict at the background remains unsettled.

\section{New directions for restorative practices?}

\section{Widening the circle of participants}

This is an Accepted Manuscript of an article published by Taylor \& Francis in Contemporary justice review on 12th July 2017, available online: http://wwww.tandfonline.com/10.1080/10282580.2017.1348899 
Some ideas for the direction in which restorative justice could develop in transitional settings may be gleaned from the initiatives which have been discussed above: co-existence workshops, the Glencree Initiative and its spin-offs and Errenteria forums. One important feature of these initiatives and the lessons which they teach relates to the rejection of approaches which are private, individualized and exclusionary in nature. Instead, these initiatives attempted to engage a wider circle of participants beyond individual victims and offenders, so as to provide a forum for group discussion and collective reflexion (even though that circle could no doubt be widened even further). In doing so, they created public spaces where normative questions and wider social conditions which are alleged to have instigated violence could be subject to collective deliberation.

To widen the circle of participants in restorative processes is to acknowledge the collective nature of the problem. As has been noted earlier, ETA was not simply an armed organization which acted in isolation. It formed part of a social and political movement which supported ETA's goals, accepted its methods in achieving them and provided an infrastructure for ETA's activities (Bullain, 2011; Muro, 2008, chapter 5). Without the support of a sizable portion of the Basque society ETA would not have survived for so long (Whitfield, 2014, pp.9-10). The collective nature of the problem signals a direction for the development of restorative justice away from merely interpersonal accommodations between individual victims and offenders and towards collective processes of critical re-assessment of the past and search for ways of co-existence in the future.

In the Basque context, where calls for the establishment of a truth commission have not been satisfied (as explained earlier in the 'Ceasefire and peace process' subsection), debates of this nature could inform the search for 'truth' and 'reconciliation' at a grassroots level between social groups subscribing to very different ideologies and having very different political aspirations. And, even if debates among small groups of ex-ETA militants, victims of various forms of violence and other interested citizens - such as those that took place in Errenteria forums, spin-offs of the Glencree Initiative and co-existence workshops - may be only very small steps towards healing resentments, they are significant simply because they reset lost communication between parties from different sides of the conflict (Andrieu, 2010). They 'remove the losses from the realm of the sacred, the never-to-be-forgiven, into the realm of the politically negotiated' (Maier, 2003, p.297). They allow the opposed parties to resume a dialogue and thus open up possibilities for political reconciliation.

Such deliberative practices bringing together people from different sides of the Basque conflict are valuable for another reason: they help to disrupt the discourse promoted by the Spanish government. As has been explained in the 'Ceasefire and peace process' subsection above, the Spanish government denies the existence of the Basque conflict and defines the problem as ETA terrorism. Far from seeking resolution of the conflict, it puts obstacles in the way of much-needed reconciliation. Restorative practices uniting adversaries and engaging them in collective reflections and debates may be viewed as an example of what Woolford and Ratner (2008) call 'informal justice counterpublics'. They are 'parallel discursive arenas where members of subordinated social groups invent and circulate counterdiscourses, which in turn permit them to formulate oppositional interpretations of their identities, interests and needs' (Fraser, 1997, p.81). Conceptualised as a form of 'informal justice counterpublics', restorative practices could initiate deliberative processes that destabilise the 'official' narrative of the past, allow for alternative meanings and understandings to emerge and present opportunities for addressing social suffering in ways that are not pre-determined by those with political power (Woolford and Ratner, 2008).

\section{Active engagement in the peace process}

This is an Accepted Manuscript of an article published by Taylor \& Francis in Contemporary justice review on 12th July 2017, available online: http://wwww.tandfonline.com/10.1080/10282580.2017.1348899 
Another important lesson which may be drawn from the initiatives outlined above is the encouragement of active individual engagement in the peace process. So, ETA prisoners participating in co-existence workshops discussed practical steps they could take to contribute towards social reconciliation and peacebuilding in the Basque country once they eventually progress to the more open 'third grade' regime (Ceberio, 2012a; Etxebarria, 2013). They talked about how through participation in various public forums they could make visible their stories of repentance and recognition of the damage caused. There have been subsequent examples of some contrite ex-ETA militants form the Nanclares group who shared publicly their stories of rejection of violence by giving media interviews (El Mundo, 2014; Iglesias, 2015; Terradillos 2016), as well as making public their experiences of apologising to their victims (Carrasco, 2013; Simón, 2015). Some of these ex-members of ETA published books which promote critical reflection of the past and peaceful coexistence (Eitb.eus, 2012b; Ormazabal, M., 2012; Rekarte, 2015). Some took part in tributes to their victims (Gastaca, 2013b; Iglesias, 2014; Segovia, M., 2013; Villameriel 2014).

Similarly, victims participating in the Glencree initiative went on to spread their message calling for a dialogue among those holding opposing views. These victims shared their testimonies in a variety of public forums, inviting a debate and encouraging not only individual but also collective transformations which could contribute to the peacebuilding process. There have been examples of the Glencree initiative victims acting as peace educators (Aizpeolea, 2015a, 2015b; eitb.eus, 2013) and victims of various forms of violence (alongside peace campaigners, ex-ETA militants, religious leaders, historians, writers, politicians and social activists) taking part in conferences, seminars, roundtable discussion and meetings aimed at promotion of co-existence and social reconciliation (Alonso, 2015; Burgueño, 2013; Eizmendi, 2012; Gorospe, 2013; Hedgecoe, 2014; Iglesias, 2013).

These examples of ex-ETA millitants and ETA victims effectively becoming peace campaigners are important. With regard to victims, their active participation in the peace process has an empowering effect and effectively releases them from the disempowering selfidentity of victims as victims (Pavlich, 2005). Instead, they acquire new political identities of peace activists campaigning to change the social conditions that had caused their suffering in the first place. As far as ex-ETA militants are concerned, their participation in peacebuilding activities could be viewed as a form of reparation of moral harm they have inflicted upon themselves and the society. Attitudes of a considerable section of the Spanish population towards ETA offenders are very hostile and punitive (CIS, 2011). This hostility makes offender reintegration and social reconciliation unlikely. If ex-members of ETA became 'agents of peace' actively seeking to reverse the moral harm they have caused, perhaps that could help to pacify the resentment and anger which victims and the rest of the society may feel towards them and encourage more forgiving attitudes. That in turn may help to pave offenders' way back into the community and facilitate political reconciliation in the Basque society. ETA's violence served to deflect attention from - and dismiss - the demands of Basque nationalists (Whitfield, 2014, 301-2; Woodworth, 2014). In the words of one commentator, "no one had done a better job than ETA at discrediting the Basque nationalist cause' (Woodworth, 2010). Maybe peace activism on the part of ex-ETA militants could help to repair some of the damage which the organization has inflicted on the very cause it sought to promote and thus contribute to advancing the project of Basque independence.

A precedent for ex-combatants being at the forefront of transition to peace in the aftermath of a violent political conflict can be gleaned from Northern Ireland, where those with violent past became key agents of conflict transformation (Ellison \& Shirlow, 2008; McEvoy \& Eriksson, 2006; Shirlow \& McEvoy, 2008). An important lesson to be learnt from the Northern Irish experience is that the involvement of former combatants in grassroots

This is an Accepted Manuscript of an article published by Taylor \& Francis in Contemporary justice review on 12 th July 2017, available online: http://wwww.tandfonline.com/10.1080/10282580.2017.1348899 
conflict transformation can bring a lot of credibility and legitimacy to reconciliation work precisely because of their violent past: they fought 'on behalf of' their communities (Shirlow \& McEvoy, 2008, p.152). These people had engaged in extreme acts of political violence yet rejected violence as a strategy. This in itself places them in an ideal position to provide moral leadership in challenging cultures of violence.

\section{Thinking outside of the framework of criminal law}

An important feature of the initiatives described above is that they did not use the framework of criminal law as a starting point. One of the main problems inherent in contemporary restorative justice theory and practice is the presupposition of a moral consensus about what constitutes crime and the resulting opposition to politicizing criminal law (Johnstone, 2011, p.120; Bottoms, 2003, p.87). Restorative justice's preference for solidifying normative standards, rather than exposing thorny moral and political issues to deliberation is questionable even in cases of 'ordinary' crime, but in situations of crime committed with political motivations it is even more problematic. Indeed, in the Basque context, the question whether one thinks within or outside of criminal law is at the heart of the conflict: should ETA's violence be classified as crimes or legitimate acts of warfare? Are ETA militants violent criminals or soldiers for Basque freedom? Does one accept the legitimacy of Spanish law or reject it as an imposition of an occupying state? In situations where moral boundaries are blurred, if not objectively, at least in the minds of some of the participants, the traditional restorative justice approach, with its assumption that the morality of what had happened is uncontestable seems ill-suited. 'Conventional' restorative justice, with its 'apolitical' stance regarding legal definitions of crime, does not seem to fit well in contexts where political issues remain unsettled. Indeed, in such contexts, by embracing legal definitions of crime and over-simplified divisions between innocent victims and culpable offenders, it operates to reinforce the hegemony of criminal law and strengthen dominant power relations (Woolford and Ratner, 2008).

Law is reductive in nature, seeking to address injustice through codified rules and thus narrowing down opportunities for critical engagement. In contrast, reconciliation, as something that belongs to the realm of ethics, requires open-endedness, so that those involved could tell their stories without artificially imposed concepts and interpretations (Christodoulidis, 2000, p.189). Law presumes a common narrative, yet in the aftermath of mass atrocities starkly oppositional narratives compete with each other (Christodoulidis, 2000, p.195). When the initiatives discussed here avoided using criminal law to define the problem, they acknowledged the existence of multiple victims and multiple forms of violence and enabled multiple narratives to emerge.

As has been explained earlier, there is a strong sense of victimisation and enduring injustice felt by the Basque nationalist left. It results from the lack of acknowledgement of crimes and violations of human rights committed against them by the Spanish state in the past and the continuation of exceptionally harsh anti-terrorist penitentiary policies and state repression of the nationalist left. In the light of that, the approach which recognises the political breadth and complexity of the problem and the existence of suffering on all sides of the conflict is likely to provide a more solid basis for the project of political reconciliation, compared to the approach adopted in the victim-mediation programme which holds to account only one party to multi-dimensional violence, treats only one type of victims as deserving reparation and helps to entrench a single 'truth' about the past.

A further consequence of the way in which these initiatives have been thinking outside of the framework of criminal law is that the scope of their campaign was no longer confined to seeking improved responses to crime. Instead, their campaign acquired a political This is an Accepted Manuscript of an article published by Taylor \& Francis in Contemporary justice review on 12th July 2017, available online: http://wwww.tandfonline.com/10.1080/10282580.2017.1348899 
character and pursued a much more ambitious agenda of political reconciliation, unlike the narrow agenda of the victim-offender mediation programme whose facilitators were resigned to the fact that restorative encounters 'do not resolve problems of co-existence in the Basque country' (Etxebarria, quoted in Olalde, 2013, p.53) and insisted that political issues did not interest them (Ríos, 2013, p.181).

\section{Conclusion}

This paper has discussed several initiatives which may be instructive for those seeking to apply restorative justice in transitional societies. It has been argued that although the 'conventional' model of restorative justice - victim-offender mediation - may be helpful in healing individual wounds, importing it from the context of 'ordinary' crime to 'political' crime is ridden with dangers. By treating specific instances of violence as isolated and disconnected events and positioning them firmly within the framework of criminal law, the victim-offender mediation model hid their political dimensions and complexity and diverted attention from unresolved political issues to individual healing and closure. When criminal law was employed to define the problem, a particular political stance was enforced which implicitly subscribed to the protection and preservation of the existing political system. The VOM model attempted to adopt an 'apolitical' stance in a situation where politics are deeply contested and assumed a moral consensus in a context where moral boundaries are disputed. It left virtually no scope for collective deliberations and norm-clarification. The criminal law's model of individual responsibility that was embraced by the programme shifted the focus away from the responsibility of numerous actors who engaged in violence with various degrees of acquiescence and direction from the State. Yet, social reconciliation is unlikely as long as only one party to mass violence is held to account and only one type of victims is treated as deserving reparation.

As noted earlier, a number of ETA's victims and offenders taking part in the mediation programme listed as one of their key motivations for participation the desire to 'help construct a Basque country free of hatred, where one day children of the assassins and the assassinated could live together without hatred' (Pascual, 2013, p.124). It should be acknowledged that the potential of 'traditional' models of restorative justice that cling to formal definitions of crime and deal with isolated instances of violence on case-by-case basis to achieve that ideal is very limited. If the aspiration were indeed to help build bridges between deeply divided sectors of the society, probably restorative practices would need to take a different form. A more promising approach, reflecting the multi-dimensional nature of violence and the scale and the complexity of the conflict, is likely to transcend the familiar image of one-to-one restorative encounters. It is likely to prefer approaches that go beyond merely addressing 'private' dimensions of wrongs defined as crimes by the criminal justice system and aim to provide public spheres where the past can be clarified, collective deliberations of politically and ethically disputed issues could unfold and the process of redefining collectively the future could begin. The experiments discussed in this paper - Errenteria forums, co-existence workshops, the Glencree Initiative and its spin-offs - may hint at some ideas for new restorative justice approaches which extend beyond exclusionary, crime-bound, 'astructurally biased' practices. Without being exhaustive, three features of these models stand out.

Firstly, these initiatives aimed to develop more socially inclusive responses, so as to encourage debates, collective reflections and critical re-assessment of the past. In a society recovering from mass violence in the shadow of an unresolved political conflict, especially where calls for the creation of a truth commission have not been satisfied, such collective truthseeking processes could function as 'mini-truth and reconciliation commissions' and forums for norm-clarification. Secondly, the initiatives promoted an active engagement of their participants as 'peace agents'. They empowered victims to play an active role in changing the This is an Accepted Manuscript of an article published by Taylor \& Francis in Contemporary justice review on 12 th July 2017, available online: http://wwww.tandfonline.com/10.1080/10282580.2017.1348899 
social conditions that had formed the breeding ground for the violence which they had suffered. They provided offenders with opportunities to repair the moral harm they had caused to themselves, the society and the very cause they had promoted by engaging in peacebuilding activities. Thirdly, by thinking beyond the conceptual horizons of criminal law, the initiatives recognized the political breadth and complexity of the problem they dealt with and sought to contribute to the project of political reconciliation by addressing multiple forms of suffering, irrespective of who the perpetrators were.

Restorative justice has been described as an 'unfinished product' (Aertsen, Arsovska, Rohne, Valiñas \& Vanspauwen, 2013, p.2). New contexts require refinements and adaptations of existing practices, as well as transcending well-established models and creating new ones to respond to local circumstances (Sharpe 2004). In the contexts of transitional societies it may be wise to re-evaluate well-established restorative justice methods that serve to divert attention away from wider political issues and towards individual concerns and thus lack the potential to disrupt the status quo. By analyzing some experiments which have emerged as part of the Basque peace process, this paper has drawn out some lessons which, it is hoped, may be helpful in imagining restorative justice approaches which aspire to transform social conditions that had generated violence to begin with and invite search for new justice possibilities.

\section{References:}

Aertsen, I., Arsovska, J., Rohne, H.-C., Valiñas, M., \& Vanspauwen, K. (Eds.) (2012). Restoring Justice after Large-Scale Violent Conflicts. Kosovo, DR Congo and the IsraeliPalestinian Case. Oxon \& NY: Routledge.

Aertsen, I., Parmentier, S., Vanfraechem, I., Walgrave, L. \& Zinsstag, E. (2013). An adventure is taking off. Why Restorative Justice: An International Journal?. Restorative Justice: An International Journal, 1, 1-14.

Agirre, J. (2012). Euskal Memoria: Recovering the memories of a rejected people. Politorbis, 54, 123-125.

Aizpeolea, L.R. (2013, December 29). El colectivo de presos de ETA reconoce el daño causado y la legalidad penitenciaria. El País. Retrieved from http://politica.elpais.com/politica/2013/12/28/actualidad/1388243625_884981.html

Aizpeolea, L.R. (2015a, May 5). Educar con la realidad del sufrimiento. El País. Retrieved from http://politica.elpais.com/politica/2015/05/29/actualidad/1432926884_001663.html

Aizpeolea, L.R. (2015b, May 28). ¿En qué se diferencia su sufrimiento del mío? El País. Retrieved from http://politica.elpais.com/politica/2015/05/28/actualidad/1432832933_639299.html

Alonso, J.M. (2015, October 31). Yo miraba para otro lado. El Mundo. Retrieved from http://www.elmundo.es/pais-vasco/2015/10/31/5634995ce2704e89718b45dc.html

Amnesty International (2007). España: sal en la herida. La impunidad efectiva de agentes de policía en casos de tortura y otros malos tratos. Retrieved from https://www.es.amnesty.org/uploads/media/Sal_en_la_herida.pdf 
Amnesty International (2009a). España: sal en la herida. Impunidad policial dos años después. Retrieved from http://www.nodo50.org/ala/spip/IMG/pdf_Espana._Sal_en_la_herida__Impunidad_policial_dos_aos_de_spues_.pdf

Amnesty International (2009b). España: salir de las sombras. Es hora de poner fin a la decención en régimen de incomunicación. Retrieved from https://www.es.amnesty.org/uploads/media/Salir_de_las_sombras.pdf

Andrieu, K. (2010). Transitional Justice: A New Discipline in Human Rights. Retrieved from http://www.sciencespo.fr/mass-violence-war-massacre-resistance/en/document/transitionaljustice-new-discipline-human-rights-0\#title4

BBC (2014, January 4). Ex presos de ETA aceptan responsabilidades. Retrieved from http://www.bbc.com/mundo/ultimas_noticias/2014/01/140104_ultnot_eta_rueda_de_prensa presos_liberados_mxa

Bengoetxea, J. (2013). Transitional Justice versus Traditional Justice: the Basque case. Journal of Ethnopolitics and Minority Issues in Europe. 12, 30-58.

Bieter, M. (2013). The Rise and Fall of ETA. The Blue Review. Retrieved from https://thebluereview.org/rise-fall-eta/\#ship

Boraine, A. (2000) Truth and Reconciliation in South Africa: The Third Way. In R.I.Rotberg and D. Thompson (Eds.) Truth v Justice. The morality of Truth Commissions. (pp.141-157). Princeton \& Oxford: Princeton University Press.

Bottoms, A. (2003). Some Sociological Reflections on Restorative Justice. In A. Von Hirsch, J.V. Roberts, A. Bottoms, K. Roach \& M. Shiff (Eds.) Restorative Justice: Competing or Reconcilable Paradigms? (pp.79-113). Oxford and Portland, Oregon: Hart Publishing.

Buckley-Zistel,S., Beck,T.K., Braun,C.\& Mieth,F. (2014). Transitional Justice Theories. London \& New York: Routledge.

Bullain, I. (2011). Revolucionarismo patriótico. El Movimiento de liberación nacional vasco $(M L N V)$. Madrid: Tecnos.

Burgueño, A. (2013, February 3). Rentería, de la leyenda negra a la búsqueda de la convivencia. El País. Retrieved from http://ccaa.elpais.com/ccaa/2013/02/03/paisvasco/1359893458_766881.html

Carmena, M., Landa, J.M., Múgica, R. \& Uriarte, J.M. (2013). Informe-base de vulneraciones de derechos humanos en el caso vasco (1969-2013). Vitoria-Gasteiz: Govierno Vasco.

Carrasco Asenguinolaza, L.M. (2013). “Aquella mañana me disponía a pedir perdón por un crimen imperdonable." Mi experiencia personal como ex-miembro de ETA ante los encuentros restaurativos. In E. Pascual Rodríguez (Ed.) Los ojos del otro. Encuentros restaurativos entre victimas y ex-miembros de ETA. (pp.277-280). Santander: Sal Terrae.

This is an Accepted Manuscript of an article published by Taylor \& Francis in Contemporary justice review on 12th July 2017, available online: http://wwww.tandfonline.com/10.1080/10282580.2017.1348899 
Castilla Jiménez, J. (2013). Incidencia de los poderes públicos en el desarrollo de los encuentros restaurativos. In Pascual Rodríguez, E. (Ed.) Los ojos del otro. Encuentros restaurativos entre victimas y ex-miembros de ETA. (pp.253-276). Santander: Sal Terrae.

Ceberio Belaza, M. (2011a, September 25). Cara a cara entre terroristas y víctimas. El País. Retrieved from http://elpais.com/diario/2011/09/25/espana/1316901601_850215.html

Ceberio Belaza, M. (2011b, September 25). "Es preciso pedir perdón para la convivencia". El País. Retrieved from http://elpais.com/diario/2011/09/25/espana/1316901602_850215.html

Ceberio Belaza, M. (2012a, February 8). "Ética y autocrítica entre rejas". El País. Retrieved from http://politica.elpais.com/politica/2012/02/07/actualidad/1328650235_134137.html

Ceberio Belaza, M. (2012b, February 8). "Fue una barbaridad pretender matarlo" El País. Retrieved from http://politica.elpais.com/politica/2012/02/07/actualidad/1328646465_063852.html

Ceberio Belaza, M. (2012c, April 29). "El preso de ETA me dijo que ponía la mente en blanco para poder matar". El País. Retrieved from http://politica.elpais.com/politica/2012/04/28/actualidad/1335644995_354578.html

Ceberio Belaza, M. (2012d, May 25). "Te quería ver la cara y decirte que me habéis devorado la vida". El País. Retrieved from http://politica.elpais.com/politica/2012/05/26/actualidad/1338055516_639919.html

Ceberio Belaza, M. (2012e, June 17). Cara a cara con el perdón: un largo y difícil camino. El País. Retrieved from http://sociedad.elpais.com/sociedad/2012/06/17/actualidad/1339960694_489456.html

Ceberio Belaza, M. (2012f, June 17). "La culpa fue nuestra y solo nuestra”. El País. Retrieved from http://politica.elpais.com/politica/2012/06/15/actualidad/1339786242_881576.html

Ceberio Belaza, M. (2013, June 26). "Mi marido también habría hablado con los terroristas que lo mataron". El País. Retrieved from http://politica.elpais.com/politica/2013/05/25/actualidad/1369499242_928460.html

CIS (2011). Estudio 2917, Barómetro de noviembre. Centro de Investigaciones Sociológicas. Retrieved from http://www.cis.es/cis/opencms/Archivos/Marginales/2900_2919/2917/e291701.html

Christie, N. (1977). Conflicts as a Property. British Journal of Criminology, 17, 1-15.

Christodoulidis, E.A. (2000). “Truth and reconciliation' at risks'. Social and Legal Studies, 9, 179-204.

Clamp, K. (2014). Restorative Justice in Transition. London and NY: Routledge.

This is an Accepted Manuscript of an article published by Taylor \& Francis in Contemporary justice review on 12th July 2017, available online: http://wwww.tandfonline.com/10.1080/10282580.2017.1348899 
Clamp, K. \& Doak, J. (2012). More than Words: Restorative Justice Concepts in Transitional Justice Settings. International Criminal Law Review, 12, 339-360.

Clark, P. (2010). The Gacaca Courts, Post-Genocide Justice and Reconciliation in Rwanda. Justice without Lawyers. Cambridge: Cambridge University Press.

Cohen, S. (2001). States of Denial. Knowing about Atrocities and Suffering. Malden, MA: Polity.

Cuadra Lasarte, S. (2009, August 28). ¡Vivan Galindo, Vera, Barrionuevo, Amedo...! ¡Vivan! Gara. Retrieved from http://gara.naiz.eus/paperezkoa/20090828/153825/es/

Doak, J. \& O'Mahony, D. (2011). In search of legitimacy: restorative youth conferencing in Northern Ireland. Legal Studies, 31, 305-325.

Douglass, W. \& Zulaika, J. (2007). Basque Anthropological Culture Perspectives. Reno Nevada: Centre for Basque Studies, University of Nevada.

Drumbl, M. (2000). Sclerosis. Retributive justice and the Rwandan genocide. Punishment and Society, 2, 287-308.

du Toit, A. (2000). The moral Foundations of the South African Truth and Reconciliation Commission: Truth as Acknowledgment and Justice as Recognition. In R.I.Rotberg and Thompson, D. (Eds.). Truth v Justice. The Morality and Truth Commissions, (pp.122-140). Princeton and Oxford: Princeton University Press.

Dyck, D. (2000). Reaching Toward a Structurally Responsive Training and Practice of Restorative Justice. Contemporary Justice Review, 3, 239-265.

Eitb.eus (2012a, June 16). Declaración íntegra de víctimas de diferentes violencias. Retrieved from http://www.eitb.eus/es/noticias/politica/detalle/907110/declaracion-victimas-textoiniciativa-glencree/

Eitb.eus (2012b, October 23). Gisasola: 'La convivencia de Euskadi es responsabilidad de todos'. Retrieved from http://www.eitb.eus/es/noticias/detalle/974397/librocarmengisasola--presentacion-libro-carmen-gisasola/

Eitb.eus (2013, November 11). Las víctimas policiales participarán en los testimonios en las aulas. Retrieved from http://www.eitb.eus/es/noticias/politica/detalle/1739946/planpazgobierno-vasco--victimas-policiales-testimonios-aulas/

Eitb.eus (2014, February 23). Los verificadores terminan la declaración en la Audiencia Nacional. Retrieved from http://www.eitb.eus/es/noticias/politica/pazeuskadi/detalle/2022226/desarme-eta--los-verificadores-declaran-audiencia-nacional/

Eitb.eus (2016, April, 4). Errenteria, sede de una experiencia 'real' de convivencia política. Retrieved from http://www.eitb.eus/es/noticias/politica/detalle/4027216/presentacionpublica-foro-dialogo-errenteria/ 
Eizmendi, M. (2012, February 4). Mirándose a los ojos con el objetivo de acercase al dolor ajeno. Naiz. Retrieved from

http://gara.naiz.eus/paperezkoa/20130204/386191/es/Mirandose-ojos-objetivo-acercasedolorajeno

Elejabarrieta Diaz, G. (2015). From freedom fighters to terrorists and back again. In I. Tellidis \& H.Toros (Eds.) Researching Terrorism, Peace and Conflict Studies. London \& NY: Routledge.

Ellison, G. \& Shirlow, P. (2008). From war to peace: informalism, restorative justice and conflict transformation in Northern Ireland. In Miller, H. (Ed.) Restorative Justice: From Theory to Practice (pp.31-57). Bradford: Emerald.

Elorza, A. (2014, May 1). "Tienen ganas y necesidad de hablar”. El País. Retrieved from http://ccaa.elpais.com/ccaa/2014/05/01/paisvasco/1398963949_958868.html

El Mundo (2014, November 11). Un documental vuelve a unir a los arrepentidos Guisasola y Alza con la viuda de Joseba Goikoetxea. Retrieved from http://www.elmundo.es/paisvasco/2014/11/24/547375ac22601d67578b4573.html

Elbal, I. (2014, February 9) La venganza y la política de alejamiento de presos. Eldiario.es. Retrieved from http://www.eldiario.es/contrapoder/alejamiento_de_presosreinsercion_social-derecho_a_las_comunicaciones-dignidad_humana_6_218788141.html

El País (2015, October 20). Sortu dice que la convivencia y los presos son incompatibles. Retrieved from http://politica.elpais.com/politica/2015/10/20/actualidad/1445343317_580199.html

Eriksson, A. (2008). Challenging cultures of violence through community restorative justice in Northern Ireland. In Miller, H. (Ed.) Restorative Justice: From Theory to Practice (pp. 231-60). Bradford: Emerald.

Etxebarria Zarrabeitia X. (2012). Justicia para convivencia. In Deusto Forum (Ed.) Justicia para la convivencia. Los puentes de Deusto (pp143-150). Bilbao: Universidad de Deusto.

Etxebarria Zarrabeitia, X. (2013). La recuperación del victimario y el paradigma restaurativo. In Pascual Rodríguez, E. (Ed.) Los ojos del otro. Encuentros restaurativos entre victimas y exmiembros de ETA (pp.281-310). Santander: Sal Terrae.

Fraser, N. (1997). Justice Interruptus: Critical Reflections on the "Postsocialist" Condition. New York: Routledge.

Gastaca, J.M. (2013a, October 10). El Gobierno "torpedea" los encuentros entre víctimas y expresos etarras. El País. Retrieved from http://ccaa.elpais.com/ccaa/2013/10/10/paisvasco/1381434178_716931.html

Gastaca, J.M. (2013b, November 22). La exetarra Gisasola abraza a la viuda de un 'ertzaina' asesinado. El País. Retrieved from http://ccaa.elpais.com/ccaa/2013/11/22/paisvasco/1385120100_118639.html

This is an Accepted Manuscript of an article published by Taylor \& Francis in Contemporary justice review on 12th July 2017, available online: http://wwww.tandfonline.com/10.1080/10282580.2017.1348899 
Goirizelaia, J. (2012). Justicia para convivencia. In Forum de Deusto (Ed.) Justicia para la convivencia. Los puentes de Deusto (pp. 165-170). Bilbao: Universidad de Deusto.

Gómez, L. (2013, October 24). El perdón de un crimen impordonable. El País. Retrieved from http://politica.elpais.com/politica/2013/10/24/actualidad/1382641750_283159.html

Gorospe, P. (2013, November 22). Iñaki Rekarte, ex preso de ETA: “A veces la vida te lleva a ser una bala perdida". El País. Retrieved from http://ccaa.elpais.com/ccaa/2013/11/22/paisvasco/1385124116_271396.html

Govier, T. (2006). Taking wrongs seriously: acknowledgement, reconciliation and the politics of sustainable peace. Amherst, NY: Humanity Books.

Hayner, P. (2011). Unspeakable Truths: Transitional Justice and the Challenge of Truth Commissions. New York and London: Routledge.

Hedgecoe, G. (2014, August 15). Political pressure stops Spain from putting Basque conflict behind it. The Irish Times. Retrieved from http://www.irishtimes.com/news/world/europe/political-pressure-stops-spain-fromputtingbasque-conflict-behind-it-1.1897239

Heiberg, M. (1989). The Making of the Basque Nation. Cambridge: Cambridge University Press.

Heiberg, M. (2007). ETA: Euskadi 'ta Askatasuna. In M. Heiberg, B. O’Leary \& J. Tirman (Eds.) Terror, Insurgency, and the State (pp. 19-50). Philadelphia: University of Pennsylvania Press.

Iglesias, L. (2012, June 16). 25 víctimas de ETA, los GAL, BVE y fuerzas policiales se unen a favor de la convivencia. El Mundo. Retrieved from http://www.elmundo.es/elmundo/2012/06/16/paisvasco/1339844079.html

Iglesias, L. (2013, November 22). El arrepentido Iñaki Rekarte: 'No es tan difícil decir que matar está mal'. El Mundo. Retrieved from http://www.elmundo.es/paisvasco/2013/11/22/528f7f8163fd3dfc3c8b456a.html

Iglesias, L. (2014, July 30). Un arrepentido de ETA honra a su víctima. El Mundo. Retrieved from http://www.elmundo.es/pais-vasco/2014/07/30/53d89660ca47419d458b456c.html

Iglesias, L. (2015, May 10). La andaluza y el etarra arrepentido (con más de ocho apellidos vascos). El Mundo.

http://www.elmundo.es/cronica/2015/05/10/554dfe5bca4741be328b457b.html

Iniciativa Glencree (2012). Iniciativa Glencree. Retrieved from

http://fundculturadepaz.org/pazyddhh/wp-

content/uploads/2014/10/55_es_EXPERIENCIAGLENCREE.pdf

This is an Accepted Manuscript of an article published by Taylor \& Francis in Contemporary justice review on 12th July 2017, available online: http://wwww.tandfonline.com/10.1080/10282580.2017.1348899 
Izquierda Abertzale (2012). Viento de solución. Retrieved from

http://www.berria.eus/dokumentuak/dokumentua885.pdf

Johnstone, G. (2011). Restorative Justice. Ideas, values, debates. ( $2^{\text {nd }}$ ed.) London and New York: Routledge.

La Vanguardia (2015, October 7). Otegi acusa al Gobierno de no querer el fin de la violencia para evitar un proceso como en Catalunya. Retrieved from

http://www.lavanguardia.com/local/pais-vasco/20151007/54437087066/otegi-

gobiernoutillizar-violencia-eta-proceso-catalan.html

Landa, J.-M. (2012). Presos: exigencias éticas y jurídicas. Justicia para convivencia.

In Deusto Forum (Ed.) Justicia para la convivencia. Los puentes de Deusto (pp.193-202).

Bilbao: Universidad de Deusto.

Landa, J.M., Echano, J., Etxebarria, X. \& Garro,E. (2014). Reinserción y personas presas de ETA análisis jurídico de su estado actual y orientaciones de futuro. Retrieved from

http://www.jmlanda.com/images/cajon-de-

sastre/1_Informe2014_Reinsercionypresos_CAST.pdf

Llewellyn, J. (2007). Truth commissions and restorative justice. In Johnstone, G. \& D. Van Ness (Eds.) Handbook of Restorative Justice (pp. 351-71). Cullompton: Willan.

Llewellyn, J. and Philpott, D. (Eds.) (2014). Restorative Justice, Reconciliation, and Peacebuilding. Oxford: Oxford University Press.

Lokarri (2012, June). Lokarri's newsletter about the Basque peace process. Retrieved from http://lokarri.org/files/File/Lokarri\%20s\%20newsletter\%20june\%202012.pdf

Lozano Espina, F. (2013). Emociones, justicia restaurativa y delitos del terrorismo: introducción a la experiencia emocional del encuentro restaurativo. In Pascual Rodríguez, E. (Ed.) Los ojos del otro. Encuentros restaurativos entre victimas y ex-miembros de ETA. (pp.75-110). Santander: Sal Terrae.

Maier, C. (2003). Overcoming the Past? Narrative and Negotiation, Remembering and Reparation: Issues at the Interface of History and the Law. In J. Torpey (Ed.) Politics and the Past. (pp.295-304). Oxford: Rowman \& Littlefield Publishers.

Martinez, I. C. (2012, June 22). Ordóñez a Lasarte: "Se lo dije, quien te tendría que perdonar está muerto". El País. Retrieved from http://politica.elpais.com/politica/2012/06/22/actualidad/1340391988_334894.html

McEvoy, K. \& Eriksson, A. (2006). Restorative Justice in Transition: Ownership, Leadership, and "Bottom-Up" Human Rights. In D. Sullivan \& L. Tifft (Eds.) Handbook of Restoraitve Justice: A Global Perspective (pp 321-35). London and New York: Routledge.

McEvoy, K. \& Mika, H. (2001). Policing, punishment and praxis: restorative justice and nonviolent alternatives to paramilitary punishments in Northern Ireland. Policing and Society, 11, 259-382.

This is an Accepted Manuscript of an article published by Taylor \& Francis in Contemporary justice review on 12th July 2017, available online: http://wwww.tandfonline.com/10.1080/10282580.2017.1348899 
McEvoy, K. \& Mika, H. (2002). Restorative justice and the critique of informalism in Northern Ireland. British Journal of Criminology, 43, 534-63.

Mika, H. (1992). Mediation Interventions and Restorative Justice: Responding to the Astructural Bias' in Messmer, H. \& Otto, H.-U. (Eds.) Restorative justice on Trial. Pitfalls and Potentials of Victim Offender Mediation - International Research Perspectives (pp. 559567). Dordrecht, The Netherlands: Kluwer.

Mika, H. \& McEvoy, K. (2001). Restorative justice in conflict: paramilitarism, community and the construction of legitimacy in Northern Ireland. Contemporary Justice Review, 3, 291319.

Minow, M. (1998). Between vengeance and forgiveness: facing history after genocide and mass violence. Boston, MA: Beacon Press.

Muro, D. (2008). Ethnicity and Violence. The Case of Radical Basque Nationalism. New York-London: Routledge.

Muro, D. (2017). ETA during democracy, 1975-2011. In R.Leonisio, Molina, F. \& Muro, D. (Eds.) ETA's terrorist campaign. From violence to politics, 1968-2015, pp.35-53. London and New York: Routledge.

Munarriz, F. (2012). El tiempo de las luces. Entrevista con Arnaldo Otegi. Bilbao: Baigorri Argitaletxea, S.L.

Naiz (2012, November 8). Víctimas de ETA y de los GAL: «Reunirnos mitigó nuestro dolor».

Retrieved from http://www.naiz.eus/es/actualidad/noticia/20131108/victimas-de-eta-y-delosgal-reunirnos-mitigo-nuestro-dolor

Naiz (2015, September 30). Fernández Díaz descarta la justicia transicional que permitiese avanzar en la paz de Euskal Herria. Retrieved fromhttp://www.naiz.eus/eu/actualidad/noticia/20150930/fernandez-diaz-afirma-que-la-unicajusticia-valida-para-el-conflicto-es-la-de-la-audiencia-nacional

Olalde Altarejos, A.J. (2013). Encuentros restaurativos en victimización generada por delitos del terrorismo: bases teóricas. In Pascual Rodríguez, E. (Ed.) Los ojos del otro. Encuentros restaurativos entre victimas y ex-miembros de ETA (pp. 21-34). Santander: Sal Terrae.

Ormazabal Elola, S. (2012). Intentos dados en la historia reciente y pasos a dar en el futuro. Retrieved from http://vientosur.info/IMG/pdf/Intentos_y_pasos_dados_Sabino_Ormazabal.pdf

Ormazabal, M. (2012, October 23). La exetarra Gisasola escribe una novela a favor de la convivencia en Euskadi. El País. Retrieved from http://ccaa.elpais.com/ccaa/2012/10/23/paisvasco/1350994256_946541.html 
Ormazabal, M. (2016, December 18). Otegi: El objetivo de España y Francia es que "ETA no se pueda desarmar". El País. Retrieved from

http://ccaa.elpais.com/ccaa/2016/12/18/paisvasco/1482066045_466824.html

Pascual Rodrígues, E. (2013). La preparación del encuentro entre las personas que han sufrido la violencia de ETA y quienes la causaron. In E. Pascual Rodríguez (Ed.) Los ojos del otro. Encuentros restaurativos entre victimas y ex-miembros de ETA (pp.111-142).

Santander: Sal Terrae.

Pavlich, G. (1996). Justice Fragmented: Mediating Community Disputes under Postmodern Conditions. London: Routledge.

Pavlich, G. (2005). Governing Paradoxes of Restorative Justice. London/Sydney/Portland, Oregon: Glasshouse Press.

Quinn, J. (2009). Reconciliation(s). Transitional Justice in Postconflict societies. Montreal \& Kingston: McGill-Queen's University Press.

Quinney, R. (1970). The Social Reality of Crime. Boston: Little, Brown and Company.

Rekarte, I. (2015). Lo difícil es perdonarse a uno mismo. Barcelona: Peninsula.

Reunión de Asociaciones y Fundaciones de Víctimas del Terrorismo (2010). Documento de bases: principios rectores para un modelo de fin de ETA sin impunidad. Retrieved from http://www.fundacionvt.org/images/fvt/documentos/DOCUMENTO-DE-BASES-PARAUNMODELO-DE-FIN-DE-ETA-SIN-IMPUNIDAD.pdf

Reyero, I. (2015, March 17). Valentín Lasarte, a Consuelo Ordóñez: «¿Puedo darte la mano?» «No. No puedes» ABC España. Retrieved from

http://www.abc.es/espana/20150317/abci-lasarte-ordoez-201503170223.html

Rohne, H.C., Arsovska, J. \& Aertsen, I. (2012). Challenging restorative justice - state based conflict, mass victimisation and the changing nature of warfare. In I. Aertsen, J. Arsovska, H.-C. Rohne, M. Valiñas \& K. Vanspauwen (Eds.) Restoring Justice after Large-Scale Violent Conflicts. Kosovo, DR Congo and the Israeli-Palestinian Case (pp.3-45). Oxon and NY: Routledge.

Roht-Arriaza, N. \& J. Mariezcurrena (Eds.) (2006) Transitional Justice in the Twenty-First Century. Cambridge: Cambridge University Press.

Ríos Martín, J.C. (2013). El encuentro personal entre quienes asesinaron perteneciendo a ETA y quienes sufrieron el horror injustificado. Descripción, análisis y reflexión. In E. Pascual Rodríguez (Ed.) Los ojos del otro. Encuentros restaurativos entre victimas y exmiembros de ETA (pp.179-228). Santander: Sal Terrae.

Rivas, J. (2012, June 16). 27 víctimas trabajan en secreto por la paz. El País. Retrieved from http://ccaa.elpais.com/ccaa/2012/06/16/paisvasco/1339850740_524030.html 
Sainz, J. (2012, December 6). Instituciones, víctimas y la izquierda abertzale debaten sobre la justicia en paz. Diariovasco.com. Retrieved from

http://www.diariovasco.com/v/20120609/politica/instituciones-victimas-izquierda-abertzale$\underline{20120609 . h t m l}$

Sainz, J. (2016, March 31). Errenteria, el laboratorio de la convivencia. El Diario Vasco. Retrieved from http://www.diariovasco.com/politica/201603/31/errenteria-laboratorioconvivencia-201603310648.html

Segovia Bernabé, J.L. (2013). Actitudes para facilitar encuentros restaurativos con las personas que pertenecieron a ETA. In E. Pascual Rodríguez (Ed.) Los ojos del otro. Encuentros restaurativos entre victimas y ex-miembros de ETA (pp.143-178). Santander: Sal Terrae.

Segovia, M. (2013, November 22). Los etarras arrepentidos Guisasola y Alza se unen a Mintegi y Urizar en el homenaje a Joseba Goikoetxea. El Mundo. Retrieved from http://www.elmundo.es/pais-vasco/2013/11/22/528f360663fd3dc00f8b456a.html

Sharpe, (2004). How Large should the Restorative Justice 'Tent' Be? In H. Zehr \& B. Toews (Eds.) Critical Issues in Restorative Justice (pp.17-31). Monsey, NY: Criminal Justice Press.

Shirlow, P. and K. McEvoy (2008). Beyond the wire. Former prisoners and conflict transformation in Northern Ireland. London: Pluto.

Simón, P. (2015, Septiembre 20). La tarde en que Maixabel se citó con el etarra que asesinó a su marido. El Mundo. Retrieved from http://www.elmundo.es/espana/2015/09/20/55fe0c5f46163fb01f8b457c.html

Sola, R. (2012, June 16). Víctimas de ambos lados presentan una reflexión compartida. Naiz. Retrieved from http://www.naiz.eus/actualidad/noticia/20120616/victimas-de-ambosladospresentan-una-reflexion-compartida-de-cinco-anos

Staiger, I. (2010). Restorative justice and victims of terrorism. In R. Letschert, I. Staiger \& A. Pemberton (Eds.) Assisting Victims of Terrorism: Towards a European Standard of Justice (pp 267-337). London, New York: Springer.

Sullivan D. \& Tifft, L. (2001). Restorative Justice: Healing the Foundations of Our Everyday Lives (Monsey, NY: Willow Tree Press).

Sullivan, D. \& L. Tifft (Eds.) (2006). Handbook of restorative justice: A global perspective. London and New York: Routledge.

Teitel, R. (2000). Transitional Justice. Oxford: Oxford University Press.

Teitel, R. (2015). Globalizing Transitional Justice. Oxford: Oxford University Press.

Terradillos, A. (2006). Vivir después de Matar. Madrid: La Esfera de los Libros.

Tutu, D. (1999). No Future Without Forgiveness. London: Rider. 
Umbreit, M.S., Coates, R.B., \& Vos, B. (2006). Victim offender mediation: an evolving evidence-based practice. In D. Sullivan \& L. Tifft (Eds.) Handbook of Restorative Justice (pp.52-62). London and New York: Routledge.

Uprimny, R. And Saffon, M. (2006). Transitional justice, Restorative Justice and Reconciliation. Some insights from the Columbian Case. Retrieved from http://global.wisc.edu/reconciliation/library/papers_open/saffon.pdf

Urkijo Azkarate, T. \& Gallizo Llamas, M. (2013). Epílogo. E. In Pascual Rodríguez (Ed.) Los ojos del otro. Encuentros restaurativos entre victimas y ex-miembros de ETA (pp.321324). Santander: Sal Terrae.

Varona, G. (2013). The meaning of impunity: what do victims, offenders and society think of restorative encounters in the context of ETA terrorism in Spain? Restorative Justice: An International Journal, 1, 215-243.

Varona, G. (2014). ETA terrorism victims' experience with restorative encounters in Spain. In I. Vanfraechem, A. Pemberton \& F.M.Ndahinda (Eds.) Justice for Victims: Perspectives on Rights, Transition and Reconciliation (pp. 322-354). Oxon: Routledge.

Villameriel, M. (2014, July 30). Uno de los condenados por el asesinato de Jáuregui acude a su homenaje y pide perdón. ElDiarioVasco.com Retrieved from

http://www.diariovasco.com/politica/201407/30/condenados-asesinato-jaureguiacude20140730000846-v.html

Villa-Vicencio, C. (1998). A different kind of justice: the South African Truth and Reconciliation Commission. Contemporary Justice Review. 1, 407-28.

Walker, M.U. (2006a). Restorative Justice and Reparation. Journal of Social Philosophy. 37, 377-395.

Walker, M.U. (2006b). Moral Repair: Reconstructing Moral Relations after Wongdoing. Cambridge: Cambridge University Press.

Weitekamp, E., Parmentier, S., Vanspauwen, K., Valiñas, M. \& Gerits, R. (2006). How to deal with mass victimization and gross human rights violations. A restorative justice approach. In U. Ewald \& K. Turkovic (Eds.) Large-Scale Victimisation as a Potential Sources of Terrorist Activities (pp.217-241). Washingron DC: IOS Press.

Whitfield, T. (2014). Endgame for ETA. Elusive Peace in the Basque Country. Hurst \& co, London.

Whitfield, T. (2015). The Basque conflict and ETA. The Difficulties of an ending. Special report 384. The United States Institute of Peace.

Woodworth, P. (2001). Dirty War, Clean Hands. ETA, the Gal and Spanish Democracy. Cork: Cork University Press.

Woodworth, P. (2010, August 20) Madrid's nightmare. Foreign Policy. Retrieved from http://foreignpolicy.com/2010/08/20/madrids-nightmare/ 
Woodworth, P. (2014, July 14). Is low-level terrorism preferable to a peaceful campaign for Basque sovereignty? Irish Times. Retrieved from

http://www.irishtimes.com/culture/books/is-low-level-terrorism-preferrable-to-apeacefulcampaign-for-basque-sovereignty-1.1861860

Woolford, A. (2009). The Politics of Restorative Justice. A critical introduction. Halifax and Winnipeg: Ferwood Publishing.

Woolford, A. \& Ratner, R.S. (2008). Informal Reckonings. Conflict resolution in mediation, restorative justice and reparations. Oxon: Routledge-Cavendish.

Zehr, H. (1990). Changing Lenses: A New Focus for Crime and Justice. Scottdale, PA: Herald Press.

Zernova, M. (2007). Restorative Justice. Ideals and Realities. Ashgate.

${ }^{i}$ However, the team of professional mediators facilitated only twelve of them. The remaining two were conducted by prison officers, and, according to the original promoters of the programme, appeared to have little - if anything - to do with the restorative justice philosophy (Castilla 2013). 